\title{
WOMEN'S RIGHTS TO SUCCESSION IN UNREGISTERED MARRIAGES: A REFERENCE TO THE INSTRUMENT OF WAȘIYYAH*
}

\author{
Akmal Hidayah Halim and \\ Mohamad Asmadi Abdullah ${ }^{* *}$
}

\begin{abstract}
It is an essential requirement for a marriage to be registered according to the procedures as provided by the law. Non-registration of a marriage leads to the non-availability of a marriage certificate, being the main proof of the existence of the marital relationship. This situation results in various legal complications in claiming the rights, including a right to property under the law of succession which arises upon the death of the spouse. Such a right, even though guaranteed by the Shari'ah, is not recognized by Malaysian law. This article seeks to examine women's rights to succession in cases of unregistered marriage with special reference to the execution of a wasiyyah as a useful instrument to protect the rights of the unregistered wives against husbands' estates.
\end{abstract}

This article is a revised version of a paper presented at the International Family Law Conference, in Kuala Lumpur, on 16-17 January 2007. Assistant Professors, Ahmad Ibrahim Kulliyyah of Laws, International Islamic University Malaysia. 


\section{INTRODUCTION}

A marriage is a beginning of a social union of two persons that involves responsibilities and rights towards each other. In Malaysia, in order to accord proper recognition to the status of a Muslim's marriage, the law requires that the marriage be properly registered according to the marriage administrative procedures as provided by the Islamic Family Law statutes. ${ }^{1}$ A proof of the existence of a marital relationship is determined based on a marriage certificate that is issued upon registration of such marriage. Although the non-registration shall not be construed to render the invalidity of a marriage that is otherwise valid, ${ }^{2}$ such a valid marriage is not recognized by the law of the country particularly in cases involving claims to the rights that are supposed to arise from the marriage contract, as registration forms an essential process in the marriage procedures.

Legal complications due to non-registration of a marriage normally occur in most cases where the parties elope to get married. In such cases, the parties normally opt not to register the marriage, as it is solemnized in breach of the statutory provisions. Although the marriage is valid according to Hukum Syara', it is not, in itself sufficient to accord the parties their entitled rights.

In light of the conundrum, this article aims to discuss Muslim women's entitlement under the law of succession in cases where their marriages are not registered as required by the written law. This writing analyzes the relevant provisions of the Islamic Family Law (Federal Territory) Act, 1984 (hereinafter referred as IFLA) as well as the principles of making a wasiyyah in favor of the entitled legal heir. The discussion focuses solely on the rights of women since they are normally subjected to losses, grief and damages in cases of unregistered marriages.

\footnotetext{
1 The main statutory reference will be the Islamic Family Law (Federal Territory) Act, 1984 (Act 303). The other Islamic Family Statutes will be referred to whenever necessary.

2 See section 34 of IFLA.
} 


\section{MARRIAGE PROCEDURES UNDER THE ISLAMIC FAMILY LAW ACT}

Prior to the solemnisation of a marriage, the law requires that each of the parties to the intended marriage has to apply for the permission to marry ${ }^{3}$ from the Registrar ${ }^{4}$ of the kariah masjid ${ }^{5}$ in which the woman is resident. If the man is resident in a kariah masjid different from that of a woman, or is resident in any State, his application shall bear or be accompanied by a statement of a Registrar of his kariah masjid or by the proper authority of the State, as the case may be, to the effect that as far as he has been able to ascertain, the matters stated in the application are true. The application must then be forwarded to the Registrar at least seven days before the proposed date of the marriage, but the Registrar may allow such shorter period in any particular case. ${ }^{6}$

In cases where either of the parties to the intended marriage is below the minimum age for marriage, or where the woman is a divorcee or where the woman has no wali from nasab, ${ }^{7}$ according to Islamic law, the Registrar shall refer the application to the Shariah Judge having jurisdiction in the place where the woman resides. ${ }^{8}$ On being satisfied of the truth of the matters stated in the application and of the legality of the intended marriage, the Registrar or the Shariah Judge, as the case may be, shall issue his permission to marry at any time after the application and upon payment of the prescribed fee.

3 By virtue of section 19 of IFLA, no marriage shall be solemnised unless a permission to marry has been given by the Registrar, or by the Shariah Judge, or by the proper authority of a State, as the case may be. According to section 2 of the IFLA, 'Registrar' means a Registrar of Muslim Marriages, Divorces and Ruju’ (a return to the original married state). The definition also includes a Deputy Registrar and an Assistant Registrar.

5 The words refer to the area in which a mosque is situated. See section 2 of IFLA.

6 See section 16 of IFLA.

7 Wali refers to the guardian of the woman. Wali nasab means the descent guardian based on lawful blood relationship. Usually, it is her father, paternal grandfather, brother or paternal uncle. See section 2 of IFLA; See also Ahmad Ibrahim, Family Law in Malaysia, $3^{\text {rd }}$ Edition, Malayan Law Journal, 1997, p. 191.

8 See section 18 of IFLA. 
After the solemnisation of the marriage, the prescribed particulars of the marriage shall be entered in the Marriage Register. The entry shall be attested to by the parties to the marriage, by the wali, and by two witnesses other than the Registrar, present at the time the marriage is solemnised. ${ }^{9}$

Apart from the requirement for the permission to marry, the law also requires that both parties to the marriage must have consented to the marriage and either:

(a) the wali of the woman has consented thereto; or

(b) the Shariah Judge having jurisdiction in the place where the woman resides or any person generally or specially authorised in that behalf by the Shariah judge has, after due inquiry in the presence of all parties concerned, granted his consent thereto as wali raja/wali hakim ${ }^{10}$ in accordance with the Islamic law. Such consent may be given wherever there is no wali by nasab available to act or if the wali cannot be found or where the wali refused his consent without sufficient reason. ${ }^{11}$

In the case where the man is already married, he cannot contract a marriage with another woman unless he has obtained the prior written permission of the court. For this purpose, the consent or views of the existing wife or wives on the proposed marriage have to be obtained. The Court shall also summon the applicant and his existing wife or wives to be present at the hearing of the application. ${ }^{12}$

\section{REASONS FOR ELOPEMENT}

The most common reasons for elopement are the refusal of a wali to give his consent to the marriage or a husband who wishes to

\footnotetext{
$9 \quad$ See section 22 of IFLA.

10 Wali raja means a wali authorised by the Ruler to give away in marriage a woman who has no wali from nasab. See section 2 of IFLA.

11 See section 13 of IFLA.

12 See section 23(4) of IFLA.
} 
contract another marriage without the knowledge of the existing wife or wives. The marriage procedures require that in such cases, a proper application must be made for the transfer of wali nasab to that of wali raja or that the consents or views from the existing wife or wives must be obtained, respectively.

As the transfer from wali nasab to wali raja is also allowed in cases where the wali nasab lives more than 2 marhalah or 60 miles $^{13}$ (a distance that enables a person to qasar or shorten his prayer) from the place where the marriage is solemnised, the parties to the marriage normally elope in order to avoid compliance with the marriage procedures. The marriage normally takes place outside Malaysia since the same procedural requirements are applicable throughout Malaysia that would frustrate the parties' intention to marry.

In most cases of elopements, the parties will not register their marriage. One of the factors for the non-registration of such a marriage is the fear of being liable to punishment. As the marriage is solemnised in breach of the statutory provisions, the parties to the marriage are considered to have committed an offence and shall be punished with a fine not exceeding one thousand ringgit or with imprisonment not exceeding six months or with both such fine and imprisonment. ${ }^{14}$ The non-registration of a marriage however, shall not be construed to render invalid a marriage that is otherwise valid. ${ }^{15}$ In other words, if the marriage has been duly performed according to Islamic law, it will be considered as a valid marriage even though it is not registered.

\section{EFFECT ON NON-REGISTRATION OF MARRIAGE}

The parties that will be most affected by the non-registration of such marriage will be the wife and the child or children, if any. This is because although the marriage may be valid under Islamic law, the wife cannot exercise her lawful rights since the marriage is not solemnised nor registered under the law. The non-availability of the marriage

$13 \quad$ See Kelantan Islamic Family Law Enactment 1983, Fourth Schedule. Corresponding legislations can be found in Malacca and Kedah.

14 See section 40(2) of IFLA.

15 See section 34 of IFLA. 
certificate will also lead to difficulties in registering the child's birth due to complexity of ascribing the paternity of the child. ${ }^{16}$ If death occurs, such a wife as well as the children cannot claim their rights as the entitled legal heirs since there is no evidence of their relationship to the deceased.

\section{THE RIGHT TO SUCCESSION}

The term 'succession' can be defined as a process of becoming entitled to the property of the deceased by operation of law or under a will. ${ }^{17}$ In the case of an unregistered marriage, the non-availability of the marriage certificate or any other evidence that can prove the existence of the marital relationship, would deny the woman's rights to claim the deceased's property under the fara $a$ i $i d$ even though she is lawfully wedded to the deceased under Islamic law. Although evidence might be adduced in order to prove the status of the marriage, the process is quite complicated and will cause hardship to the particular wife. As the term 'succession' also means the process of becoming entitled to the property by a will or wasiyyah, ${ }^{18}$ this article seeks to analyse the law relating to the execution of a wasiyyah in order to determine the possibility of the husband executing a will in favour of the wife to ensure that she gets her rightful share.

\section{THE MAKING OF WAȘIYYAH UNDER ISLAMIC LAW}

Wașiyyah is a means of disbursing one's wealth upon death. According to Pearl, it is an optional testamentary succession and is different from compulsory succession that is the fara $\bar{a}^{\prime} i d$ system. ${ }^{19}$ This optional disposal of property by way of a will is an absolute right of the

\footnotetext{
$16 \quad$ Noraini Md. Hashim, "Is Registration of Marriage Important?," retrieved on $2^{\text {nd }}$ December 2006, http://www.hijrahmedia.com/proto/ iidl2/artikel/elope.php.

17 LB Curzon, Dictionary of Law, $3^{\text {rd }}$ Edition, International Law Book Services, 1989, p. 422.

18 The words 'will' and 'wassiyyah' will be hereafter used interchangeably.

19 Pearl, David, A Textbook on Muslim Personal Law, $2^{\text {nd }}$ edition, London: Croom Helm, 1987, p. 138.
} 
deceased. It is not effective until the testator's death. Similar to compulsory succession, the ownership of the property disposed of by means of a bequest is transferred to the beneficiaries only upon death.

It is to be noted that making a wașiyyah is a practice recommended to all Muslims. It was originally incumbent upon every Muslim following the revelation of the Qur'anic verse al-Baqarah (2): 180, which apparently states that there is an obligation upon a Muslim close to death to make a bequest in favour of his parents and next of kin. This is also supported by a hadith, "It is not permissible for any Muslim who has something to will, to stay for two nights without having his last will and testament written and kept ready with him." ${ }^{20}$ According to the four Sunni schools of law, this original ruling was abrogated by the revelation of the Qur'anic verses al-Nisā' (4):11,12 and 176 and the hadith of the Prophet 'no wasiyyah in favour of legal heirs.'

However, despite the abrogation, there are scholars namely Țāwus, Qatādah and Jābir bin Zayd who state that making a bequest in favour of relatives who do not inherit under inheritance law, remains incumbent. ${ }^{21}$ Furthermore, Abū Thawr is of the view that making of bequest is incumbent upon one who is under a religious duty to discharge other's rights such as trust property and debts. According to him, this is to ensure that these rights are correctly transferred to the rightful recipients and such a bequest could prevent any unnecessary ruin of these rights. ${ }^{22}$

\section{LIMITATION OF WASTIYYAH ON THE RECIPIENT}

Even though a Muslim is allowed to dispose of his property by way of a wasiyyah, and by that means he is permitted to freely select the beneficiaries and confer upon them rights to his estate effectively upon his death, such a right is not absolute. His right to make a wasiyyah

See Șahīh al-Bukhārī, translated by Khan, Muhammad Muḥsīn, The Translation of the Meanings of Saḥ̄ḥ al-Bukhārī, Riyāḍ: Dār al-Salām, 1997, vol. 4, p. 15.

21 Al-Shawkānī, Imām Muḥammad bin c'Alī bin Muḥammad, Nayl Awțār, Beirut: Dār al-Kutub al-'Ilmiyyah, 1995, vol. 3, p. 37.

$22 \quad$ Ibid, p. 37. 
is subject to limitations. A wașiyyah that exceeds the prescribed limits would constitute an ultra vires wasiyyah, unless the consent or refusal of the entitled heirs is obtained. ${ }^{23}$

There is no single Qur'anic verse prohibiting a Muslim from making a bequest in favour of legal heirs. This limitation is therefore based on a number of sound Prophetic traditions that state that making a bequest in favour of legal heirs is not permitted. ${ }^{24}$ With respect to these Prophetic traditions, the Hanafīs opinion is that if the deceased makes a bequest in favour of the heir who is entitled to his property under inheritance, such a bequest, if not consented to by the other legal heirs, is invalid. This is on the basis that bequests made in favour of legal heirs need the approval of the other legal heirs. The deceased has no right to make a bequest in favour of a legal heir and if he/she does so the rights of the other legal heirs are encroached upon. This is the reason for the need for the approval of the other legal heirs because their rights have been affected. The Hanafīs base their argument on the hadith that narrates that if other legal heirs consent, the bequest is effective. ${ }^{25}$ The other three schools of law hold the opinion that the bequest is void; if the other legal heirs agree, the legatee is entitled to the property bequeathed but on the ground that it is a gift or hibah from them. This opinion is based on the hadith that Allah has specified the details of the rights of every legal heir, and hence they have no further right under a bequest.

According to al-Qaradāwī, when the verses of inheritance were revealed, even though the entitled legal heirs rights to bequests were

23 Coulson, N.J., Succession in the Muslim Family, London: Cambridge University Press, 1971, pp. 242- 243.

$24 \quad$ There are a number of Prophetic traditions but with different versions that do not allow making bequests in favour of legal heirs. The difference is only in the matter of the words of the narrations. They carry the same meaning, i.e. a bequest is not allowed to be made in favour of legal heirs. See Tanzil-ur-Rahman, vol. 2, pp. 457-461. Example is the hadith 'No wașiyyah in favour of wärith.'

Ibn 'Abidīn al-Shāmī, Hāshiyah Rad al-Mukhtār calā Dur al-Mukhtār, Bākistān: Maktabah Rashīdiyyah Ku'tah, vol. 6, 1404H, p. 656. The Hanafīs accept another version of the hadith, which carries the addition of the words "except when the heirs permit the same." See also alȘancānī, Muḥammad ibn Ismāc̄il al-Amīr al-Yamanī, Subul al-Salām Syarh Bulūgh al-Marām min Jamci Adillah al-Aḥkām, Beirut: Dār alKutub, p. 204. 
abolished, the disentitled legal heirs rights to bequests remained in existence. ${ }^{26}$ Such heirs have no rights under inheritance and hence are entitled to the bequest. This is sanctioned by the hadith, from which we can identify the reason behind the prohibition of bequests being made in favour of legal heirs, i.e. those who are entitled to the deceased's property under inheritance law are not entitled to bequests. Since Allah has prescribed their rights to the deceased's wealth by way of succession, they have no right to the deceased's wealth by way of bequest. ${ }^{27}$

Based on the above arguments, it is clear that 'wärith' refers to the legal heir who is entitled to the deceased's property under inheritance law. The Arabic word 'wārith' means a person who inherits one's property upon the latter's death. ${ }^{28}$ This means that if the legal heir is either de jure or de facto excluded from inheritance or is disqualified due to the presence of any impediment to inheritance that affects his or her entitlement, any bequest made by the deceased in their favour is valid. This is similar to the conclusions of al-Zuhaylī and Coulson who state that the ban of making a will in favour of legal heirs operates only against one who is a legal heir of the testator at the time of the latter's death. ${ }^{29}$ Coulson seems to disagree with the translation of 'wärith' as 'an heir' as used by the language of the law, which actually follows the popular usage, because according to him such translation includes a mere potential heir who could in turn be disentitled under farä'i $i d$ law. ${ }^{30}$

\section{LIMITATION OF WASTIYAH ON THE QUANTUM}

The whole version of the hadìth is that $\mathrm{Sa}^{\mathrm{c}} \mathrm{ad}$ bin Abī Waqās narrates that the Prophet came to visit me in the year of the farewell

26 Al-Qaraḍāwī, Fatwa Terkini Wanita dan Keluarga, translated by H.Mohd. Roihan M.A, Kuala Lumpur: Pustaka Shuhada, 1996, p. 172.

27 Abū Imāmah narrated: "I heard the Prophet says: Allah has already given to each entitled relative his proper entitlement. Therefore, no bequest in favour of a legal heir.” Al-Șancānī, Subul al-Salām, p. 204.

$28 \quad$ Al-Mucjam al-Wasit t, Majma ${ }^{c}$ al-Lughah al-'Arabiyyah, Istanbul: alMaktabah al-Islāmiyyah, n.d., vol.1\&2, p. 1034.

29 Al-Zuhaylī, al-Fiqh al-Islāmī wa Adillatuhū, $3^{\text {rd }}$ edition, Damshiq:

Dār al-Fikr, vol. 8, p. 42. See also Coulson, p. 241.

30 Coulson, p. 241. 
pilgrimage when I was afflicted with a severe illness. I said to him: "O Prophet, you see how ill I am. I have property and no heir except my daughter. Shall I then give away two-thirds of my property as alms?” He replied "No." I said "A half then?” He still said "No." I then asked "A third?” He replied: "A third. And a third is much. It is better that you leave your heirs rich than you should leave them destitute, begging from their neighbours." ${ }^{31}$ There are different versions reported in other books of hadith, which carry the same effect: that the quantum of bequest is limited to $1 / 3$ of the whole estate of the deceased..$^{32}$

In this regard, there are two circumstances that need to be considered, namely the situation where the deceased leaves behind heirs and that where there is no heir. In the former case, the four Sunni schools of law hold the same opinion that a bequest exceeding the limit of $1 / 3$ is valid provided the consent of the entitled legal heirs are obtained. This is due to the fact that the right to the whole property, on the death of the deceased, passes immediately to the legal heirs and hence, they have absolute freedom to do as they will with such a right. If such a bequest is approved it becomes effective. If it is not, it is still valid but only up to the portion of $1 / 3$, because the exceeding part is regarded as an encroachment on the rights of the legal heirs.

In the second situation, the Hanafīs, the Shāficīis and the Hanbalīs are of the opinion that a bequest exceeding $1 / 3$ of the whole estate is valid. The idea of limiting the bequest to $1 / 3$ is to protect the interests of the legal heirs and if no legal heir exists, the issue of encroachment does not arise. In such a case, there is no need for consent to be obtained from the sovereign (as represented by the bayt al-māl or state treasury) as the sovereign is not strictly an heir but is vested with the property by way of escheat. ${ }^{33}$

The Mālikīs, on the other hand, hold the view that in such cases, the deceased has no right to make a bequest of more than $1 / 3$ of his

31

32

33

Khan, translation of Ṣaḥị̣ al-Bukhārī, p. 16. See also Coulson, N.J. p. 214.

For example in another hadìth narrated by $\mathrm{Mu}^{\mathrm{C}} \mathrm{a} d \mathrm{dh}$ bin Jabal that Allah had conferred upon a Muslim an alms of 1/3 of his property in the time of death approaching as an addition for his good deeds. See al-Ṣanª̄nī, p. 108.

Coulson, p. 50. 
wealth because the bayt al-māl is regarded as the residuary heir and neither the ruler nor his representative has the right to give consent. But if the administration of the bayt al-māl is not as outlined by Islamic law and involves such things as corruption and the unfair distribution of property, the deceased is allowed to bequeath all his property in a manner to please Allah. ${ }^{34}$

\section{THE ONE-THIRD RULE AND A NON-LEGAL HEIR BENEFICIARY UNDER MALAYSIAN LAWS}

A Muslim is allowed to make a will to dispose of up to one-third of his or her property. If the will is for more than one-third, the consent of the legal heirs must be obtained in order for it to be effective. This principle was adopted in Shaik Abdul Latif, Halima and Janiah $v$ Shaik Elias Bux..$^{35}$ In this case, the deceased, Shaik Baboo Bux, had disposed of all of his properties, movable and immovable. He directed that his estate, subject to certain trusts, should be distributed equally between his adopted son, Shaik Abdul Latif, his two widows, Halimah and Jainab, and his daughter, Fatimah, an infant. In addition to the above-mentioned persons the deceased left other surviving relatives, viz., a sister named Jaigun and two brothers named Shaik Elias Bux and Shaik Ali Bux. Under Islamic law, the testator's two brothers, together with Jaigun, the deceased's sister are among the deceased's heirs and are entitled to the deceased's estate. Under the will however, they were to receive nothing and neither would the deceased's daughter receive the share due to her according to Islamic law. Before the trial judge, the plaintiff, Shaik Elias

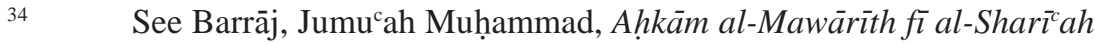
al-Islāmiyyah, ' ${ }^{2}$ mmān: Dār al-Fikr li al-Nashr wa al-Tawzīc , 1981, p. 133. [1940] 9 MLJ 229. In this case the Court held that the maximum portion for a bequest is one-third of the property. In Abdul Rahim v Abdul Hameed \& Anor [1983] 2 MLJ 78, the Court declared invalid the disposition of property by way of a will by the deceased for the reason that it exceeded one-third of the estate and hence it was against the Islamic law.
} 
Bux prayed for a judgment declaring the will inoperative in so far as it attempted to deprive the testator's daughter, the plaintiff himself as a deceased brother, the second brother and the sister of the shares they were entitled to as heirs under Islamic law. There was no contention from the defendant that there had been any consent to the will from them. The trial judge held that the will was inoperative with respect to such part of the property bequeathed to the testator's adopted son as it exceeded the one-third of the estate permissible to leave to a stranger, and also inoperative in so far as it deprived the testator's two brothers and sister of their legal shares as heirs. On appeal, the Court unanimously upheld the decision of the trial judge. The Court held that under Islamic law a testator has the power to dispose of not more than one-third of the property belonging to him at the time of death; and that the residue of such property must descend in fixed proportions to those declared by the Islamic law to be his heirs unless the heirs consent to a deviation from this rule.

A will is not supposed to be made in favour of the heirs who are entitled under the Islamic law of succession. If it is made in favour of any of them it is subject to the approval of other heirs, whose shares are affected by the will. The affected legal heirs must give their consent in order to make the will operative. Mere silence does not amount to consent. According to the Court, once the other legal heirs' approval is obtained, the will is operative and the consent is regarded as their donations in favour of the legatee. In Amanullah Bin Haji Ali Hassan v Hajjah Jamilah Binti Shek Madar, ${ }^{36}$ the will executed by the deceased was for more than one-third of the property and furthermore, was in favour of the heirs. The Court held that the will was void on the basis that it purported to dispose of more than a third of the estate and to benefit the testator's heirs. The counsel for the plaintiff argued that the silence of the relatives after the will had been read should be taken as consent by the beneficiaries to the disposition by the will. Rejecting the argument, Syed Othman J. stated:

36

[1975]1 MLJ 30. See also Siti bte. Yatim v Mohamad Nor bin Bujai (1928) 6 FMSLR 135 or [1983] JH 217, and Haji Hussain v Liah bt Lerong \& Ors (1940) MLJ 98. In these two cases, the Muslim testators had bequeathed their properties in favour of their children without obtaining the consent of the other affected legal heirs. The Court gave judgment invalidating the wills. 
"To my mind, in Muslim law, before the court can accept that an heir consents to a will where required, it must be shown that the will was validly made and that the heir declares his approval to the disposition; and if the will is invalid the question of consent does not arise. The effect of a declaration of approval to a disposition under a properly made will, according to a jurist, is that the heir donates his share to the person taking under the disposition. See page 261 Minhaj al-Talibin. In the case here I can see no evidence that any beneficiary present declared his approval to the plaintiff taking the whole of the estate. Considering the circumstances in which the document was made, I am convinced that the plaintiff was taking advantage of the situation by exerting his status as the eldest son in the family and that he knew no one would dare to challenge him by reason of his status, and particularly at that time when the others were concerned with the deceased who was on the throes of death, all he seemed to care was to get the deceased's estate to himself by any means."

With respect to the consent of the affected legal heirs to the bequest made in favour of other heirs, or made in excess of the quantum of one-third, it is the opinion of the majority of Muslim scholars that the approval must be obtained after the death of the testator. Approval obtained prior to the deceased's death has no effect. The reason for this is that the will itself becomes effective only after the death and prior to that, the legal heirs have no right to the property. Only the Mālikīs make a distinction between the approval made during the testator health and that made during his or her death sickness. During his or her health, the heirs have no right at all to the estate but during the death sickness, the testator is not absolutely free to make any transaction regarding his or her property. He or she is allowed to make a will within the limit of one-third and the remaining two-thirds is left for the benefit of the legal heirs. In this connection, the contention by the defence counsel in Amanullah's case that the heirs consented to the bequest while it was being read to them, has no legal effect. This is the opinion of the majority of Muslim jurists, including the Shāficīs. 
Moreover, the Court's refusal to accept the defence counsel's argument, that silence amounts to consent, is sound on the basis that if the heirs' consented to the bequest, according to the Court, it would amount to their donating their shares to the beneficiaries. However, in Islamic law a donation requires the donor to declare definitely the intention to donate; such a declaration can be either by word or conduct but not by mere silence. ${ }^{37}$ It is therefore submitted that the Court's decision to refuse to accept the argument that silence is tantamount to consent in the above case relating to the approval of the affected heirs is in accordance with the principles of Islamic law.

\section{A BEQUEST IN FAVOUR OF UNREGISTERED SPOUSE AND THE QUANTUM}

It is now quite clear that a husband can make a will in favour of his runaway bride. This is to ensure the benefit under the will is transferred to her legitimately. She cannot claim her right as a wife to the deceased's wealth under the far $\bar{a}^{\prime} i d \underline{d}$ system because their marriage is not registered. Her hope to benefit from husband's property is very much dependant on the agreement of other legal heirs. If they do not agree and refuse to include her as an heir, she will get nothing even though under Islamic law, she is actually entitled.

Accordingly, such a husband is under a religious responsibility to make such a wasiyyah in order to protect the rights of his legitimate wife. Otherwise her rights will be jeorpardised and her entitlement will be impeded by the procedural law. The other legal heirs have two options; they can recognize her as a legitimate wife and legal heir of the deceased or treat the wasiyyah as valid and without the need for their consent.

In relation to the quantum of the bequest, it should be equal to the share of a wife under the fara $\bar{a}^{\prime} i d$ system. Although the maximum quantum of bequest is allowed up to one-third of the property, it is submitted that the bequest in favour of the runaway bride should not be more than her entitlement under the far $\bar{a}^{\prime} i d$. After all, the making of such a bequest is only necessary in order to ensure that her share as a 
lawful wife is protected. If the quantum exceeds her entitlement under far $\bar{a}$ 'i $i$, the consent from other legal heirs must be obtained so that the division of the deceased's property is just and fair enough to all entitled legal heirs.

\section{CONCLUSION}

In light of the above discussion, it is evident that a marriage that fulfills the requirement of a valid marriage is valid from the perspective of Islamic law, regardless of whether such a marriage is registered or not. One of the effects of a valid marriage is the mutual entitlement of succession between a husband and his wife. However, due to the requirement of registration of marriages imposed by the laws applicable in the various states of Malaysia, it becomes very difficult for a bride especially, to establish her right to her husband's property after the latter's death. In order to circumvent this barrier, it is suggested that a husband should be held responsible for preparing a will to make provision for his legitimate wife under an unregistered marriage with a view to avoiding any dispute under the Islamic law of succession in the event that her husband pre-deceases her. 